University of Nebraska - Lincoln

DigitalCommons@University of Nebraska - Lincoln

USDA National Wildlife Research Center - Staff Publications
U.S. Department of Agriculture: Animal and Plant Health Inspection Service

\title{
$6-2012$
}

\section{Home Ranges Of Female Rio Grande Turkeys (Meleagris Gallopavo Intermedia) In Southern Texas}

Eric Reyes Ramirez

Texas A\&M University-Kingsville

Megan C. Clayton

Texas A\&M University-Kingsville, Megan.Clayton@ag.tamu.edu

Cody W. Lawson

Texas A\&M University-Kingsville

Stephen M. Burns

Texas A\&M University-Kingsville

Rafael Guarneros-Altimirano

Texas A\&M University-Kingsville

See next page for additional authors

Follow this and additional works at: https://digitalcommons.unl.edu/icwdm_usdanwrc

Reyes Ramirez, Eric; Clayton, Megan C.; Lawson, Cody W.; Burns, Stephen M.; Guarneros-Altimirano, Rafael; Demaso, Stephen J.; Kuvlesky, William P. Jr.; Hewitt, David G.; Ortega-Santos, J. Alfonso; and Campbell, Tyler A., "Home Ranges Of Female Rio Grande Turkeys (Meleagris Gallopavo Intermedia) In Southern Texas" (2012). USDA National Wildlife Research Center - Staff Publications. 1187. https://digitalcommons.unl.edu/icwdm_usdanwrc/1187

This Article is brought to you for free and open access by the U.S. Department of Agriculture: Animal and Plant Health Inspection Service at DigitalCommons@University of Nebraska - Lincoln. It has been accepted for inclusion in USDA National Wildlife Research Center - Staff Publications by an authorized administrator of DigitalCommons@University of Nebraska - Lincoln. 


\section{Authors}

Eric Reyes Ramirez, Megan C. Clayton, Cody W. Lawson, Stephen M. Burns, Rafael Guarneros-Altimirano, Stephen J. Demaso, William P. Kuvlesky Jr., David G. Hewitt, J. Alfonso Ortega-Santos, and Tyler A.

Campbell 


\section{HOME RANGES OF FEMALE RIO GRANDE TURKEYS (MELEAGRIS GALLOPAVO INTERMEDIA) IN SOUTHERN TEXAS}

Eric Reyes Ramirez, Megan C. Clayton, Cody W. Lawson, Stephen M. Burns, Rafael Guarneros-Altimirano, Stephen J. DeMaso, William P. Kuvlesky, Jr., David G. Hewitt, J. Alfonso Ortega-Santos, and Tyler A. Campbell*

Caesar Kleberg Wildlife Research Institute, Texas A $\mathcal{E} M$ University-Kingsville, 700 University Boulevard, MSC 218, Kingsville, TX 78363 (ERR, MCD, CWL, SMB, RGA, WPK, DGH, JAOS)

Texas Parks and Wildlife Department, 4200 Smith School Road, Austin, TX 78744 (SJD)

United States Department of Agriculture, Animal and Plant Health Inspection Service, Wildlife Services, National Wildlife Research Center, Texas A EंM University-Kingsville, 700 University Boulevard, MSC 218, Kingsville, TX 78363 (TAC)

Present address of SJD: Gulf Coast Joint Venture, United States Fish and Wildlife Service, 700 Cajundome Boulevard, Lafayette, LA 70506

*Correspondent: tyler.a.campbell@aphis.usda.gov 
ABSTRACT-We captured and placed radiotransmitters on 27, 37, and 51 female Rio Grande turkeys (Meleagris gallopavo intermedia) on the Encino, Norias, and Laureles divisions of King Ranch, respectively, in Brooks, Kenedy, and Kleberg counties, Texas. Mean annual sizes of home ranges were 838-5,867 ha, which were larger than most individual holdings of private property in Texas. Conservation plans should take this into consideration.

RESUMEN-Capturamos y fijamos radiotransmisores en 27, 37, y 51 hembras del pavo silvestre (Meleagris gallopavo intermedia) del río Grande en las divisiones Encino, Norias, y Laureles del rancho King, respectivamente, en los condados de Brooks, Kenedy, y Kleberg en Texas. Los tamaños promedios anuales del rango de hogar fueron de 838 a 5,867 ha, los cuales fueron de mayor tamaño que la mayoría del tamaño de las propiedades privadas en Texas. Los planes de conservación deberían considerar la relevancia de estos resultados.

Home range was defined by Burt (1943) as the area traversed by an individual in its normal activities of gathering food, mating, and caring for young. Badyaev et al. (1996) believed that extensive movements by individuals among parts of an annual home range can be costly in terms of reduced survival, noting that familiarity with a given area can improve foraging efficiency, avoidance of predators, and reproductive success, and that this familiarity is a significant factor contributing to social dominance. Consequently, nonmigratory animals should select habitats that provide all their annual needs in the smallest possible area (Badyaev et al., 1996).

In wild turkeys (Meleagris gallopavo), social status is determined largely by age because young individuals are dominated by older individuals (Healy, 1992). Badyaev et al. (1996), studying eastern turkeys (M. g. silvestris) in Arkansas, discovered that adults had smaller home ranges during the breeding season and greater overlap in home ranges among seasons than juveniles. Moreover, ranges of females in spring and prenesting were the largest reported for eastern turkeys because of high predation on nests, which may cause extensive movements associated with selection of nesting sites (Badyaev et al., 1996). Also in Arkansas, juvenile females occupied larger home ranges than adult females, heavier females occupied smaller home ranges than lighter females, and nesting individuals had smaller home ranges than nonnesting individuals (Thogmartin, 2001). Similar relationships were observed in Rio Grande turkeys (M. g. intermedia) in the Panhandle of Texas (Hall et al., 2006).

With exception of a study evaluating home ranges relative to grazing systems of livestock (Schulz and Guthery, 1987), movements of Rio Grande turkeys in southern Texas have not been studied. Information on size of home range is needed to understand spatial relationships and develop or refine conservation plans. Our objectives were to estimate and compare size of home ranges and core areas annually and in breedingnesting periods by age and nesting status.

Our study was conducted on three sites in Brooks, Kenedy, and Kleberg counties on the Encino, Norias, and Laureles divisions of King Ranch. All three sites were within the Rio Grande Plains Ecoregion (Gould, 1975), which is a mixed-brush community (Scifres, 1980). Common habitat included live oak (Quercus virginianus) woodlands, honey mesquite (Prosopis glandulosa) savannahs, and mesquite-mixed-brush shrublands. Soils included Mollisols, Vertisols, Alfisols, and Entisols (Hatch and Pluhar, 1993). Grasses included big bluestem (Andropogon gerardii), little bluestem (Schizachyrium scoparium), yellow Indiangrass (Sorghastrum nutans), eastern gamagrass (Tripsacum dactyloides), bufflegrass (Cenchrus ciliaris), and King Ranch bluestem (Bothriochloa ischaemum). Dominant forbs included croton (Croton), dayflower (Commelina erecta), partridge pea (Chamaecrista fasciculate), and sunflower (Helianthus annuus). Average rainfall was 64 $\mathrm{cm}$ and average length of growing season was 240 days (Lehmann, 1984).

We captured female turkeys on the Encino, Norias, and Laureles divisions during November 2003-February 2005. We captured them with rocket nets or walk-in traps baited with cracked corn. We estimated age from shape of tail feathers, coloration, and banding patterns (Dimmick and Pelton, 1994). We fitted turkeys with a backpack harness containing a mortality-sensing radiotransmitter (Advanced Telemetry Systems, Inc., Isanti, Minnesota) and released them at site of capture. All capturing and handling procedures were approved by the Institutional Animal Care and Use Committee at Texas A\&M University-Kingsville.

We collected diurnal and crepuscular radiotelemetry data during December-July 2003-2005. We estimated locations of turkeys using radioreceivers and hand-held, 6-element, Yagi antennas, by recording 3-5 compass azimuths $\leq 15 \mathrm{~min}$ apart from fixed georeferenced telemetry stations. We used program LOAS (Ecological Software Solutions, Sacramento, California) to generate coordinates (Universal Transverse Mercator) and errorellipse areas of estimated locations. We attempted to locate each individual 3-7 times/week. We omitted all locations when error-ellipse area was $\geq 5$ ha.

We used the animal-movement extension (Hooge and Eichenlaub, 1997) of ArcView GIS 3.2 (Environmental Systems Research Institute, Redlands, California) to generate areas used. We used the fixed-kernel method (Worton, 1989) to generate 95\% home-range areas and 
Table 1-Mean annual size (ha) of home range (1 December-31 July) and mean size of home range in the breeding-nesting period (1 March-30 June) calculated using the 95\%-fixed-kernel method and mean annual size (ha) of core area and mean size of core area in the breeding-nesting period calculated using the 50\%-fixed-kernel method for female Rio Grande wild turkeys (Meleagris gallopavo intermedia) studied at three sites on King Ranch, Brooks, Kenedy, and Kleberg counties, Texas, 2003-2005.

\begin{tabular}{|c|c|c|c|c|c|c|c|c|c|c|c|c|c|}
\hline Study site & Period & \multicolumn{6}{|c|}{ Size of home range } & \multicolumn{6}{|c|}{ Size of core area } \\
\hline Encino & Annual & 22 & 1,548 & 405 & 8 & 1,529 & 533 & 22 & 196 & 55 & 8 & 247 & 113 \\
\hline Norias & Annual & 6 & 838 & 131 & 1 & 1,124 & & 6 & 123 & 25 & 1 & 112 & \\
\hline Norias & Breeding-nesting & 25 & 530 & 77 & 4 & 347 & 161 & 25 & 100 & 18 & 4 & 58 & 33 \\
\hline Laureles & Breeding-nesting & 37 & 263 & 47 & 4 & 218 & 104 & 37 & 43 & 7 & 4 & 55 & 30 \\
\hline
\end{tabular}

$50 \%$ core areas. We generated home-range and core areas annually (1 December-31 July) and during the breedingnesting period (1 March-30 June). For kernel distributions both annually and for breeding-nesting periods, we used least-squares cross validation as the smoothing parameter (Silverman, 1986). We only included turkeys in analyses if they were radiomonitored throughout a period. Also, we only included animals in analyses if $>30$ locations were collected throughout a period.

We determined nesting status (nesting or nonnesting) by monitoring movements daily during the nesting period. We inferred that adult females were incubating eggs on nests when estimates of locations were similar over $\geq 2$ consecutive days. After 14 days of incubation, we confirmed nesting activities by obtaining visual observations of adult females and nests by homing into each nesting female. We conducted monitoring of nests during early morning to allow females that we flushed time to return to nests.

We used a one-factor ANOVA to compare size of annual home range using the $95 \%$ kernel method and size of core area using the $50 \%$ kernel method for juveniles or adults (PROC MIXED; Littell et al., 2006). Our model considered age as a fixed effect. We used a one-factor ANOVA to compare size of home range in the breeding-nesting period using the 95\%-kernel method and size of core area using the 50\%-kernel method between nesting or nonnesting. Our model considered nesting or nonnesting as a fixed effect. We reported means $\pm S E$.

We captured 27, 37, and 51 females on the Encino, Norias, and Laureles divisions of King Ranch, respectively. Mean size of home range annually was $838-5,867$ ha (Table 1). We determined annual sizes of home ranges to differ by age $\left(F_{1,73}=4.80, P=0.032\right)$, with adults $(1,204$ \pm 184 ha, $n=62$ ) exhibiting smaller annual home ranges than juveniles $(2,832 \pm 1,400$ ha, $n=13)$. Similarly, we determined annual sizes of core areas varied by age $\left(F_{1,73}\right.$ $=4.92, P=0.030)$, with adults $(180 \pm 32$ ha, $n=62)$ displaying smaller annual core areas than juveniles (513 \pm 296 ha, $n=13$ ).

Mean sizes of home ranges in the breeding-nesting period were 218-616 ha (Table 1). Sizes of home ranges in the breeding-nesting period varied by nesting status $\left(F_{1,105}=8.19, P=0.005\right)$, with nesting individuals $(170 \pm$ 33 ha, $n=38$ ) having smaller home ranges than nonnesting individuals (536 \pm 93 ha, $n=69)$. Sizes of core areas in the breeding-nesting period differed by nesting status $\left(F_{1,105}=3.80, P=0.054\right)$, with nesting individuals (38 \pm 10 ha, $n=38$ ) exhibiting smaller core areas than nonnesting individuals (99 \pm 22 ha, $n=69)$.

Size of annual home ranges of female Rio Grande turkeys in our study were similar to Hall et al. (2006; 8843,092 ha) from the Panhandle of Texas. In southwestern Kansas, female Rio Grande turkeys displayed large annual home ranges (4,401-5,962 ha) and investigators suggested long-distance movements in search of suitable habitat in a fragmented landscape as an explanation (Hall et al., 2006). In our study, juveniles on the Laureles division exhibited large annual home ranges $(5,867 \mathrm{ha})$. Throughout much of the Laureles division, features of landscape are comparatively homogeneous; however, suitable habitat for roosting is limited (Phillips, 2008). Therefore, we surmise that juveniles had to travel long distances in search of suitable roosting habitat because of their subordinate social status. Other factors that contribute to large home ranges of juveniles may be drought and grazing pressure.

Sizes of annual core areas have not been described for female wild turkeys. Core areas are important because animals spend most of their time there and they often contain critical resources. Our mean estimates of sizes of annual core areas of $112-1,143$ ha can serve as a comparison for future studies.

Similar to other studies of wild turkeys (Badyaev et al., 1996; Thogmartin, 2001; Hall et al., 2006), we detected that annual home ranges of adults were smaller than those of juvenile females. This observation provides further evidence that subordinate juveniles disperse long 
distances in search of suitable habitat and minimal intraspecific aggression, whereas adults display site-fidelity to areas containing critical resources (Healy, 1992; Badyaev et al., 1996).

We determined that adult females engaged in nesting activities maintained smaller home ranges and core areas than nonnesting adult females during the breedingnesting period. Further, we expected to observe the large percentage of juveniles not participating in nesting activities (63\%). However, we were surprised that such a large percentage of adults did not engage in nesting activities $(62 \%)$ given above-average precipitation during our study (National Oceanic and Atmospheric Administration, http://www.cpc.ncep.noaa.gov/products/ monitoring_and_data/drought.shtml). Predation on nests and abandonment of nests by turkeys has been observed elsewhere in southern Texas (Ransom et al., 1987) and this may have occurred at our sites as well.

Landowners and managers seeking to promote conservation of wild turkeys often seek information related to size of a property needed for effective management. The annual sizes of home ranges that we observed, as well as sizes of home ranges from turkeys across their range (Hall et al., 2006), are greater than most individual holdings of private property in Texas (i.e., $<200$ ha; Wilkins et al., 2000). Conservation plans should take this into consideration and, in many situations, it may be appropriate to establish management cooperatives with adjacent landowners who share common goals.

This project was funded by Texas Parks and Wildlife Department, National Wild Turkey Federation, and Texas Chapter of the National Wild Turkey Federation. We appreciate logistical support provided by personnel of King Ranch Incorporated and Caesar Kleberg Wildlife Research Institute at Texas A\&M University-Kingsville. We thank J. Delgado-Acevedo for translating the abstract to Spanish. This is manuscript 10131 of the Caesar Kleberg Wildlife Research Institute.

\section{Literature Cited}

Badyaev, A. V., W. J. Etges, and T. E. Martin. 1996. Ecological and behavioral correlates of variation in seasonal home ranges of wild turkeys. Journal of Wildlife Management 60:154-164.

BurT, W. H. 1943. Territoriality and home range concepts applied to mammals. Journal of Mammalogy 24:346-352.

Dimmick, R. W., And M. R. Pelton. 1994. Criteria of sex and age. Pages 169-214 in Research and management techniques for wildlife and habitats (T. A. Bookhout, editor). Fifth edition. Wildlife Society, Bethesda, Maryland.

Gould, F. W. 1975. Texas plants: a checklist and ecological summary. Texas Agricultural Experiment Station Miscellaneous Publication 585:1-121.

Hall, G. I., M. J. Butler, M. C. Wallace, W. B. Ballard, D. C. Ruthyen, III, R. L. Houchin, R. T. Huffman, R. S. Phillips, and R. D. Applegate. 2006. Rio Grande wild turkey home ranges in the southern Great Plains. Proceedings of the Southeastern Association of Fish and Wildlife Agencies 60:36-42.

Hatch, S. L., ANd J. Pluhar. 1993. Texas range plants. Texas A\&M University Press, College Station.

Healy, W. M. 1992. Behavior. Pages 46-65 in The wild turkey: biology and management (J. G. Dickson, editor). Stackpole Books, Harrisburg, Pennsylvania.

Hooge, P. N., and B. Eichenlaub. 1997. Animal movement extension to ARCVIEW. Version 1.1. United States Geological Survey, Anchorage, Alaska.

Lehmann, V. W. 1984. Bobwhites in the Rio Grande plains of Texas. Texas A\&M University Press, College Station.

Littell, R. C., G. A. Milliken, W. W. Stroup, R. D. Wolfinger, And O. Schabenberger. 2006. SAS for mixed models. Second edition. SAS Institute, Inc., Cary, North Carolina.

Phillips, C. E. 2008. Structure of winter Rio Grande wild turkey roosts in South Texas. M.S. thesis, Texas A\&M University, Kingsville, Kingsville.

Ransom, D., Jr., O. J. Rongstad, and D. H. Rusch. 1987. Nesting ecology of Rio Grande turkeys. Journal of Wildlife Management 51:435-439.

Schulz, P. A., And F. S. Guthery. 1987. Effects of short duration grazing on wild turkey home ranges. Wildlife Society Bulletin 15:239-241.

ScIFrES, C. J. 1980. Brush management: principles and practices for Texas and the Southwest. Texas A\&M University Press, College Station.

Silverman, B. W. 1986. Density estimation for statistics and data analysis. Chapman Hall, London, United Kingdom.

Thogmartin, W. E. 2001. Home-range size and habitat selection of female wild turkeys (Meleagris gallopavo) in Arkansas. American Midland Naturalist 145:247-260.

Wilkins, R. N., A. Hays, D. Kubenka, D. Steinbach, W. E. Grant, A. E. Gonzalez, and M. E. KJelland. 2003. Texas rural lands. Texas Cooperative Extension, Texas A\&M University System Publication B-6164:1-26.

Worton, B. J. 1989. Kernel methods for estimating the utilization distribution in home-range studies. Ecology 70:164-168.

Submitted 23 July 2010. Accepted 12 June 2011. Associate Editor was Floyd W. Weckerly. 